\title{
Soft Skills Development Strategies for Computer Engineering and Information Technologies Undergraduate Students Devised in the Process of Learning English
}

\author{
Oleksandr Malykhin \\ Department of Didactics \\ Institute of Pedagogy of NAES of \\ Ukraine \\ Kyiv, Ukraine \\ malexvladi@gmail.come
}

\author{
Nataliia Aristova \\ Department of International \\ Relations and Research Cooperation \\ Institute of Pedagogy of NAES of \\ Ukraine \\ Kyiv, Ukraine \\ n.aristova.na@gmail.com
}

\author{
Susanna Melikova \\ Specialised English School No. 107 \\ Kryvyi Rih, Ukraine \\ sussana2020@ukr.net
}

\begin{abstract}
The aim of the study was to devise soft skills development strategies for Computer Engineering and Information Technologies undergraduate students in the process of learning English. The research consisted of total 347 Computer Engineering and Information Technologies undergraduate students including 45 female students $(\mathbf{1 3 . 0 0 \% )}$ and 302 male students $(87.00 \%)$ aged from 17 to 21. The research which was non-experimental in nature was conducted at four higher education institutions in Ukraine between October 2020 and November 2020. To reach the main aim of the study the team of researchers developed a web-based questionnaire containing open-ended and closedended questions. The use of the web-based questionnaire seemed to be quite logical for collecting the data necessary for devising soft skills development strategies for Computer Engineering and Information Technologies undergraduate students in the process of learning English taking into account the situation connected with the Covid-19 pandemic. The respondents who volunteered to take part in the survey were sent a link to the web-based questionnaire and guaranteed the complete anonymity. The data analysis covered processing of information collected from the anonymous web-based survey, displaying the data obtained in the form of tables and figures, devising soft skills development strategies based on research results and drawing general conclusions. The findings obtained enabled the authors to present six development strategies aimed at enhancing soft skills among Computer Engineering and Information Technology undergraduate students that could be applied in the process of learning English: a) combination of competence-based, action-oriented and
\end{abstract}

blended-learning approaches in the English for Specific. Purposes classroom, b) integration of formal, non-formal and informal learning, c) participation in specially focused network professional communities, d) use of open educational resources for learning English, e) use of open professionally-oriented educational resources, f) introduction of learning-style based activities in the English for Specific Purposes classroom for boosting students' soft skills.

Keywords - Computer Engineering and Information Technologies undergraduate students, English for Specific Purposes, soft skills, soft skills development strategies.

\section{INTRODUCTION}

Most researchers and educators seem to concur that improvements in soft skills are important prerequisites for students' comprehensive development, their readiness to adapt and respond to the challenges of our time. What is more, soft skills enable students to fully and meaningfully take part in all the decisions that affect their personal lives and future professional achievements. But nevertheless, the review of the scientific literature suggests that there is no consensus on the number of soft skills future entrants into the labour market should be able to gain while studying at universities. Thus, for instance, Klaus, Rohman, and Hamaker [1] identifies the following list of soft skills, namely, being self-aware, trustworthiness, conscientiousness, adaptability, critical 
thinking, attitude, initiative, empathy, confidence, integrity, self-control, organizational awareness, likability, influence, risk taking, problem solving, leadership, time management.

The range of soft skills suggested by Shakir includes communication skills, critical thinking, problem solving skills, team work, lifelong learning and information management skills, entrepreneurship skills, ethics, professional moral skills, leadership skills [2].

Even more detailed classification of soft skills is presented by Majid et al. [3], to be exact: communication skills, leadership skills, persuasion skills, negotiation skills, conflict management and time management skills, problem solving and creative problem solving skills, teamwork spirit, personal effectiveness, strategic thinking, positive work attitude, willingness to learn, passion towards work

The classification of soft skills suggested by Robles [4] could be regarded as a bit more generalized when comparing with the previous ones. The researcher identifies the following soft skills, namely: integrity, communication, courtesy, responsibility, social skills, positive attitude, professionalism, flexibility, teamwork, and work ethic.

Even more generalized classification offered by Balachandar, Jayam, and Jawaharrani [5] comprises communication skills including English communication skills, interactive listening skills, enthusiasm and positive attitude, team building skills.

According to OECD [6], soft skills essential for young adults encompass critical thinking, creative thinking, learning-to-learn, self-regulation, empathy, selfefficacy, responsibility, collaboration, manual skills, life skills, abilities to mobilise one's capacities and abilities to use and manipulate materials, tools, equipment and artefacts.

In our research, "Council Recommendation of 22 May 2018 on key competences for lifelong learning (Text with EEA relevance) (2018/C 189/01)" [7] is the major background document for identifying a set of soft skills essential for personal fulfillment of future entrants to the labor market. Soft skills comprise problem solving skills, critical thinking, team work skills, creativity, computational thinking, self-regulation, analytical thinking, resilience, intercultural skills and communication skills including negotiation skills.

The main aim of the research was to devise soft skills development strategies for Computer Engineering and Information Technologies undergraduate students in the process of learning English for Specific Purposes (ESP) in line with the results collected by researchers through a web-based survey.

\section{MATERIALS AND METHODS}

Subjects of the study were 347 Computer Engineering and Information Technologies undergraduate students including 45 female students (13.00\%) and 302 male students $(87.00 \%)$ aged from 17 to 21 . The research sample was selected with the use of convenience sampling technique. The research which was nonexperimental in nature was conducted at Kyiv National University of Technologies and Design (Kyiv, Ukraine), Taras Shevchenko National University of Kyiv (Kyiv, Ukraine), Interregional Academy of Personnel Management (Kyiv, Ukraine), H. S. Skovoroda Kharkiv National Pedagogical University (Kharkiv, Ukraine) between October 2020 and November 2020.

To obtain information necessary for devising soft skills development strategies for Computer Engineering and Information Technologies undergraduate students in the process of learning English for Specific Purposes, the researchers developed a web-based questionnaire which included open-ended and closed questions. The designed open-ended and closed-ended questions were aimed at finding out what soft skills were considered to be the most important for Computer Engineering and Information Technologies undergraduate students, what activities used in the process of learning English seemed to be the most effective for their enhancement. Two closed-ended questions of the web-based questionnaire also concerned age and gender of respondents. The respondents were asked to rate the level of importance of identified soft skills according to a 5-point Likert-type scale (5 - extremely important; 4 - very important; 3 moderately important; 2 - slightly important; 1 - not important). The open-ended questions were aimed at finding out the range of disciplines which could promote the enhancement of soft skills and what way these skills could be useful for their professional activity.

After receiving anonymous responses from the webbased survey, the researchers started processing information obtained from respondents. This enabled them to display all the data collected, to devise and substantiate soft skills development strategies for Computer Engineering and Information Technologies undergraduate students in the process of learning English and to draw general conclusions.

\section{RESULTS AND DISCUSSION}

The results of the research among Computer Engineering and Information Technologies undergraduate students are given in Table 1. 
TABLE 1 RESPONDENTS' VIEWS ON THE IMPORTANCE OF SOFT SKILLS FOR THEIR PROFESSIONAL DEVELOPMENT

\begin{tabular}{|c|c|c|c|c|c|}
\hline Soft skills & 总 & 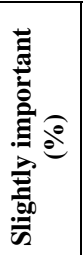 & 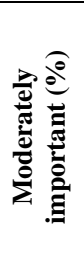 & 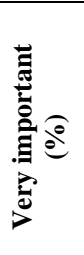 & 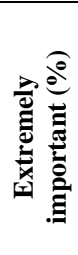 \\
\hline $\begin{array}{ll}\begin{array}{l}\text { Problem } \\
\text { skills }\end{array} & \text { solving } \\
\end{array}$ & 0.00 & 0.00 & 10.00 & 10.00 & 80.00 \\
\hline Critical thinking & 0.00 & 0.00 & 20.00 & 15.00 & 65.00 \\
\hline Team work skills & 0.00 & 0.00 & 5.00 & 30.00 & 65.00 \\
\hline Creativity & 0.00 & 0.00 & 10.00 & 25.00 & 65.00 \\
\hline $\begin{array}{l}\text { Computational } \\
\text { thinking }\end{array}$ & 0.00 & 0.00 & 20.00 & 40.00 & 40.00 \\
\hline Self-regulation & 0.00 & 0.00 & 5.00 & 15.00 & 80.00 \\
\hline Analytical thinking & 0.00 & 0.00 & 10.00 & 45.00 & 45.00 \\
\hline Resilience & 0.00 & 0.00 & 10.00 & 20.00 & 70.00 \\
\hline Intercultural skills & 0.00 & 5.00 & 0.00 & 35.00 & 60.00 \\
\hline $\begin{array}{l}\text { Communication } \\
\text { skills including } \\
\text { negotiation skills }\end{array}$ & 0.00 & 0.00 & 0.00 & 25.00 & 75.00 \\
\hline
\end{tabular}

Concerning the questions aimed at finding out the range of disciplines which could promote the enhancement of soft skills and what way these skills could be useful for their professional activity the following results were obtained. Among the disciplines that could be regarded as potentially useful for developing Computer Engineering and Information Technologies undergraduate students' soft skills the majority of respondents (more than $75.00 \%$ ) listed the English for Specific Purposes and Psychology. The obtained results explain the desire of researchers to design an optional course aimed at combining both the improvement of Computer Engineering and Information Technologies undergraduate students' English language proficiency and the enhancement of their soft skills. The learning content was organized within the units titled in accordance with the identified soft skills, namely, problem solving skills, critical thinking, team work skills, creativity, computational thinking, self-regulation, analytical thinking, resilience, intercultural skills and communication skills including negotiation skills. And nearly all the respondents (more than 90\%) confirmed the importance of the identified soft skills for their professional development and career growth.

The findings obtained enabled the authors to present six development strategies aimed at enhancing soft skills among Computer Engineering and Information Technology undergraduate students that could be applied in the process of learning English: a) combination of competence-based, action-oriented and blended-learning approaches in the ESP classroom, b) integration of formal, non-formal and informal learning, c) participation in specially focused network professional communities, d) use of open educational resources for learning English, e) use of open professionally-oriented educational resources, f) introduction of learning-style based activities in the ESP classroom for boosting students' soft skills.

Strategy 1 - Combination of competence-based, action-oriented and blended-learning approaches in the ESP classroom. The results of the literature review clearly indicates that despite the high number of methodological approaches developed and substantiated by scholars and practitioners, there is still no universal methodological approach whose usage in the educational process helps to improve students' hard and soft skills. It proves the fact that the main ideas of several methodological approaches should be applied for enhancing both hard and soft skills among students of different specialties. Each individual case of choosing methodological approaches or a combination of methodological approaches is determined by educational results to be achieved upon completion of training programmes. As far as Computer Engineering and Information Technologies undergraduate students are concerned, the consideration of the fundamental principles of the competence-based, action-oriented and blended-learning approaches enables university lecturers to find effective ways of improving the identified soft skills. Considering that "language learning should be directed towards enabling learners to act in real-life situations, expressing themselves and accomplishing tasks of different natures" [8, p. 29], the use of the actionoriented approach enables to develop students' soft skills by means of a variety of problem solving, team building, creative thinking and communicative activities. To reach success in today's globalized world higher education graduates should acquire a wide range of skills and competences. It is explained by the fact that skills and competences they acquire while studying at university "enable them to participate fully in society and manage successfully transitions in the labour market" [9, p. 7]. The publication of a book "The Action-oriented Approach: A Dynamic Vision of Language Education" by Enrica Piccardo and Brian North [10] provides new perspectives on language and education. Following the authors of the book the term "the action-oriented approach" refers to the choice made by CEFR itself to reach its mission, i.e. to contribute transparency and coherency to the vast and complex field of language use and language education; it does not intend to push a particular methodological agenda [11]. For today the foreign language proficiency is becoming increasingly critical to both personal and societal development. Taking into consideration the fact that the action-oriented approach turned to be the object of particular attention from the side of educators involved in foreign languages teaching and also from the creators of foreign languages training curricula, new methodological knowledge 
appeared aimed at upgrading foreign languages content that can meet learners' requirements. The discussed methodological improvements in foreign language education are not resulted in terms of practices and policies of education but also in terms of societal importance. The issues mentioned became the starting points for making a suggestion that foreign language learning could be converted into some certain effective way of boosting educational mechanisms and techniques guaranteeing the development of students' soft skills. The process of teaching ESP at higher education institutions is aimed at providing students with the proper scope of foreign language knowledge and communicative skills and it proves the rightness of the combination of competence-based and action-oriented approaches. Current transformations taking place in the system of higher education in general and in the professional training of Computer Engineering and Information Technologies undergraduate students in particular tend to combine best practices of distance learning and in-person instruction (especially taking into account the situation connected with the Covid-19 pandemic). That is the reason why implementation of the main ideas of the competence-based and action-oriented approaches should be influenced by the major issues of blended learning as a featured methodological approach. Thus, we consider the combination of competence-based, action-oriented and blended-learning approaches in the ESP classroom as one of the most significant strategies to be realized in the process of learning English targeted at enhancing soft skills among Computer Engineering and Information Technologies undergraduate students. The strategy implies the fulfillment of the following assignments: 1) to carry out a theoretical review of scientific literature aimed at understanding how methodology is conceived in teaching and learning English for Specific Purposes; 2) to analyze the mentioned language teaching approaches, principles they are based on, learning outcomes they are aimed at, the advantages and disadvantages of their use in the foreign language instruction process focused on development of soft skills; 3) to understand what influences the choice of the mentioned combination of approaches for improving Computer Engineering and Information Technologies undergraduate students' languages competence and soft skills [12].

Strategy 2 - Integration of formal, non-formal and informal learning. The team of researchers conducted the study aimed investigating the influence of combining formal, non-formal and informal learning on improving Computer Engineering and Information Technologies undergraduate students' training through the increase in their general self-efficacy [13]. It became the basis for defining the second influential strategy targeted at enhancing soft skills among Computer Engineering and Information Technologies undergraduate students in the process of learning English as the integration of formal, non-formal and informal learning. The realization of this strategy implies the fulfillment of the following tasks: 1) to investigate the influence of combining formal, nonformal and informal learning on improving Computer Engineering and Information Technologies undergraduate students' soft skills; 2) to share the experience gained in the process of learning English focused on enhancing Computer Engineering and Information Technologies undergraduate students' soft skills.

Strategy 3 - Participation in specially focused network professional communities. Considering that entering the labor market, many young specialists (and Computer Engineering and Information Technologies specialists are not an exception) are not often ready to realize their full potential [14]. As the practice shows the reason for this lies in the lack of special professionallyvaluable experience, lack of special knowledge of how to share innovative ideas with other colleagues and even fear to ask for advice on issues of concern. The authors are convinced that "there is no easy way out of this situation, but due to the spread of the Internet, easy access to information resources, services and specially focused network communities specialists of different spheres can discuss acute problems, share personal experiences in coping with them, improve their selfefficacy and, as a result, achieve their creative potential and contribute greatly to the organization or company they work for" [15, p. 229]. So within the research presented we took a decision to determine the third strategy to be realized in the process of English learning focused on enhancing Computer Engineering and Information Technologies undergraduate students' soft skills as the participation in specially focused network professional communities. The additional reason for taking such a decision is the fact that the majority of network professional communities use the English language as a means for exchanging ideas and information. And participation in the mentioned network professional communities can provide a great deal of opportunities for improving Computer Engineering and Information Technologies undergraduate students' soft skills. To be exact, the students in the process of combining English learning and being active participants of the network professional communities can improve the skills identified by European Commission [16], namely: problem solving skills, critical thinking, team work skills, creativity, computational thinking, self-regulation, analytical thinking, resilience, intercultural skills and communication skills including negotiation skills etc. And the listed soft skills are regarded as being of great value for Computer Engineering and Information Technologies undergraduate students by the team of researchers. The implementation of the strategy implies the following tasks: 1) to define information regarding the rate of Computer Engineering and Information Technologies undergraduate students' participation activity in professional learning networks; 2) to assess the 
influence of networked professional learning on developing Computer Engineering and Information Technologies undergraduate students' soft skills, on the one hand, and foreign language proficiency, on the other.

Strategy 4 - Use of open educational resources for learning English. Considering the results of the studies aimed at investigating open educational resources for learning English [17; 18], a decision was made to define the fourth strategy which is to use open educational resources for learning English to be implemented while developing Computer Engineering and Information Technologies undergraduate students' soft skills. The English language training practice demonstrates that the use of open educational resources significantly intensifies students' cognitive activity, the development of lifelong learning skills, on the one hand, and the scope of the soft skills declared in the research, on the other hand. The implementation of this strategy is targeted at accomplishing the sequence of the following objectives: 1) to analyze conceptual approaches for specifying the essence of the notion of "soft skills" and the variety of the content meanings of the identified soft skills, i.e. problem solving skills, critical thinking, team work skills, creativity, computational thinking, self-regulation, analytical thinking, resilience, intercultural skills and communication skills including negotiation skills; 2) to substantiate the choice of learning content (in the process of English learning focused on soft skills development) taught to Computer Engineering and Information Technologies undergraduate students. The various open educational resources can be used for developing students' soft skills, for instance, "Encyclopedia Britannica” [19], “Learn English Online” [20], “TED Talks” [21], "BBC Learning English” [22] etc.

Strategy 5 - Use of open professionally-oriented educational resources. Following the logic of identifying the fourth strategy we have come to the conclusion to define the fifth strategy as to use open professionallyoriented educational resources. But the choice of such open professionally-oriented educational resources should be imposed on Computer Engineering and Information Technologies undergraduate students. And this choice they make in accordance with their professional interests, the existing professional experience gained within the subject-matter disciplines. The strategy implementation implies the fulfillment of the following tasks: 1) to analyze conceptual approaches of the understanding of the peculiar features of the range of professions and the fields of Economy where Computer Engineering and Information Technologies students can work after graduating from higher education institutions; 2) to broaden professionally-valuable learning content by means of applying to open professionally-oriented educational resources (presented in the English language). The number of open professionally-oriented educational resources cannot be limited for use. It means that all resources found by Computer Engineering and Information Technologies undergraduate students can be used in the process of learning English aimed at the development of their soft skills.

Strategy 6 - Introduction of learning-style based activities in the ESP classroom for boosting students' soft skills. The sixth strategy that was determined by the team of researchers to be realized in the process of English learning focused on Computer Engineering and Information Technologies undergraduate students' soft skills development implied the introduction of learningstyle based activities in the ESP classroom for boosting students' soft skills. The realization of this strategy was aimed at addressing the following challenges: 1) to determine the learning styles of Computer Engineering and Information Technologies undergraduate students by using the modality questionnaire by O’Brien [23; 24]; 2) to provide assistance in both acquiring the foreign language knowledge and developing soft skills by means of offering learning activities according to Computer Engineering and Information Technologies undergraduate students' learning styles.

\section{CONCLUSIONS}

The research conducted enabled to devise and substantiate six development strategies aimed at enhancing soft skills among Computer Engineering and Information Technology undergraduate students that could be applied in the process of learning English: a) combination of competence-based, action-oriented and blended-learning approaches in the ESP classroom, b) integration of formal, non-formal and informal learning, c) participation in specially focused network professional communities, d) use of open educational resources for learning English, e) use of open professionally-oriented educational resources, f) introduction of learning-style based activities in the ESP classroom for boosting students' soft skills. The implementation of strategies devised by researchers in the process of learning English at higher education institutions significantly affects the development of soft skills among Computer Engineering and Information Technologies undergraduate students. The time spent on learning each individual unit can vary from 6 to 10 hours (as optimally recommended by the authors). The willingness of students to study the English language in such an upgraded way (in this very case as being combined with the process of soft skills enhancement) proves the fact that the learning content of the obligatory courses of English at universities is to meet the current requirements of the present-day globalized society. The development of such courses should be targeted at improving professional training of Computer Engineering and Information Technologies undergraduate students as future entrants to the labor market 


\section{REFERENCES}

[1] P. Klaus, J.M. Rohman, and M. Hamaker, The hard truth about soft skills: workplace lessons smart people wish they'd learned sooner. HarperCollins e-books, 2007. [E-book] Available http://www.r-

5.org/files/books/ethology/corporate/behaviour/Peggy_KlausThe_Hard_Truth_About_Soft_Skills-EN.pdf

[2] R. Shakir, "Soft skills at the Malaysian institutes of higher learning”, Asia Pacific Education Review, vol. 10, pp. 309 - 315, 2009. Doi: https://doi.org/10.1007/s12564-009-9038-8

[3] S. Majid, Z. Liming, S. Tong, and S. Raihana, "Importance of Soft Skills for Education and Career Success”, International Journal for Cross-Disciplinary Subjects in Education, Special Issue vol. 2, no. 2, pp. 1036-1042, 2012. [Online]. Available: https://pdfs.semanticscholar.org/797c/f7e83148968b38c525fe713 1027dce564b40.pdf [Accessed Dec. 10, 2020].

[4] M. M. Robles, "Executive Perceptions of the Top 10 Soft Skills Needed in Today's Workplace”, Business Communication Quarterly, vol. 75, no. 4, pp. 453-465, 2012. Doi: 10.1177/1080569912460400

[5] S. Balachandar, R. Jayam, and Jawaharrani, “A Study on the Soft Skill Requirements and Suggested Training for Student Community at Nursing Colleges in Today's Context”, International Journal of Control Theory and Applications, vol. 9, no. 41, pp. 1363-1371, 2016. [Online]. Available: https://www.researchgate.net/publication/307964226_A STUDY ON THE SOFT SKILL REQUIREMENTS AND SUGGEST ED TRAINING FOR STUDENT COMMUNITY AT COLLE GES IN TODAY'S_CONTEXT [Accessed Dec. 15, 2020].

[6] OECD Future of Education and Skills 2030 Concept Note, 2019. [Online]. Available: https://www.oecd.org/education/2030project/teaching-and-

learning/learning/skills/Skills_for_2030_concept_note.pdf [Accessed Nov. 20, 2020].

[7] Council Recommendation of 22 May 2018 on key competences for lifelong learning (Text with EEA relevance) (2018/C 189/01), 2018. [Online]. Available: https://eur-lex.europa.eu/legalcontent/EN/TXT/PDF/?uri=CELEX:32018H0604(01)\&from=LT [Accessed 25 Nov., 2020].

[8] Common European Framework of Reference for Languages: Learning, Teaching, Assessment, 2001. [Online]. Available: https://rm.coe.int/common-european-framework-of-reference-forlanguages-learning-teaching/16809ea0d4 [Accessed Dec. 17, 2020].

[9] Common European Framework of Reference for Languages: Learning, Teaching, Assessment, 2001. [Online]. Available: https://rm.coe.int/common-european-framework-of-reference-forlanguages-learning-teaching/16809ea0d4 [Accessed Dec. 17, 2020].

[10] E. Piccardo and B. North, The Action-oriented Approach: A Dynamic Vision of Language Education. Multiligual Matters (August 2, 2019).

[11] E. Piccardo and B. North, The Action-oriented Approach: A Dynamic Vision of Language Education. Multiligual Matters (August 2, 2019).
[12] O. Topuzov, O. Malykhin, and N. Aristova, “The Right Mix of Approaches in the English Language Teaching: Achieving Desired Learning Outcomes in the ESP Classroom”, In Proc. SIE International Scientific Conference 'May 22 ${ }^{\text {nd }}$ 2020, vol. 5, pp. 512-526, 2020. Doi: http://dx.doi.org/10.17770/sie2020vol5.4818

[13] O. Malykhin and N. Aristova, "Improving computer Engineering and information technologies undergraduate students' training through combination of formal, non-formal and informal learning”, In Proc. ETR International Scientific and Practical Conference, vol. 2, pp. 208-213, 2019. doi: https://doi.org/10.17770/etr2019vol2.4113

[14] O. V. Malykhin and N. O. Aristova, "Investigation into participation activity rate of foreign languages teachers in specially focused network pedagogical communities", The New Pedagogical Review, vol. 53, pp. 227-238, 2018. [Online]. Available: http://www.educationalrev.us.edu.pl/e53/a19.pdf [Accessed Oct. 10, 2020].

[15] O. V. Malykhin and N. O. Aristova, "Investigation into participation activity rate of foreign languages teachers in specially focused network pedagogical communities", The New Pedagogical Review, vol. 53, pp. 227-238, 2018. [Online]. Available: $\quad$ http://www.educationalrev.us.edu.pl/e53/a19.pdf [Accessed Oct. 10, 2020].

[16] Council Recommendation of 22 May 2018 on key competences for lifelong learning (Text with EEA relevance) (2018/C 189/01), 2018. [Online]. Available: https://eur-lex.europa.eu/legalcontent/EN/TXT/PDF/?uri=CELEX:32018H0604(01)\&from=LT [Accessed 25 Nov., 2020].

[17] O. V. Malykhin, N. O. Aristova and V. I. Kovalchuk, "Investigation into open educational resources for learning English in developing future philologists' instrumental values". In Proc. SIE International Scientific Conference 'May 24th-25th 2019, vol. 3, pp. 512-526, 2019. Doi: https://doi.org/10.17770/sie2019vol3.3833

[18] O. V. Malykhin, N. O. Aristova and L. M. Dybkova, "Developing Future English Teachers' Overall Communicative Language Ability: Open Educational Resources Usage” Revista Romaneasca Pentru Educatie Multidimensionala, vol. 11(4Sup1), pp. 134-155, 2019. Doi: https://doi.org/10.18662/rrem/182

[19] Encyclopedia Britannica. 2020. [Online]. Available: https://www.britannica.com/ [Accessible Jan. 14, 2020].

[20] Learn English Online. 2020. [Online]. Available http://learnenglish.britishcouncil.org/ [Accessed Jan. 20, 2020].

[21] TED Talks. 2020. [Online]. Available https://www.ted.com/talks [Accessed Apr. 18, 2020].

[22] BBC Learning English. 2020. 2020. [Online]. Available https://www.bbc.co.uk/learningenglish [Accessed Jan. 14, 2020].

[23] L. O’Brien, “Learning Styles: Make the Student Aware”, National Association of Secondary School Principals Bulletin, vol. 73, pp. 85-89, 1989.

[24] L. O’Brien, Learning channel preference checklist. Rockville, MD: Specific Diagnostic Services, 1990. 